\title{
SERUM HAPTOGLOBINS IN HAEMOLYTIC STATES
}

\author{
BY \\ J. A. OWEN,* G. C. de GRUCHY,* AND H. SMITH \\ From the Clinical Biochemical Laboratories and the Department of Medicine, St. Vincent's \\ Hospital, Melbourne
}

(RECEIVED FOR PUBLICATION MAY 23, 1960)

Serum haptoglobin levels have been studied in patients with a number of haemolytic disorders.

In general, serum haptoglobins were low in patients with increased haemolysis. Values were reduced irrespective of whether haemolysis occurred intravascularly or extravascularly.

The reduction was related to the amount of haemoglobin destroyed per day.

Serum haptoglobins may be raised in certain neoplasms and infections and during adrenocortical steroid hormone therapy. A rise in haptoglobins due to one of these factors may mask a fall due to haemolysis. Thus a normal or raised serum haptoglobin does not necessarily exclude a haemolytic process.

It is now well recognized that the serum haptoglobins may be reduced in haemolytic states (Chevallier and Wolpé, 1945 ; Nosslin and Nyman, 1958 ; Allison, 1958 ; Neale, Aber, and Northam, 1958). The determination of haptoglobins in serum is thus of potential value in the detection of haemolysis. The purpose of this paper is to record serum haptoglobin levels in a number of different types of haemolytic disorders, to assess the relation of rate and site of haemolysis to the serum haptoglobin levels, and to examine the value of this estimation as an aid in the diagnosis of haemolytic states.

\section{Methods}

Serum haptoglobins were measured by a colorimetric procedure (Owen, Better, and Hoban, 1960a). The results have been expressed in terms of methaemoglobin-binding capacity (mg./100 ml.). This method gives a mean normal value $(n=150)$ of $91 \mathrm{mg} . / 100 \mathrm{ml}$. with a range ( \pm 2 S.D.) of 11 to 172 mg. $/ 100 \mathrm{ml}$.

Haemoglobin was measured photometrically as oxyhaemoglobin. Reticulocytes were stained with cresyl blue (Dacie, 1956). Erythrocyte counts were not performed, so that absolute reticulocyte counts could not be computed. As an approximate absolute index of reticulocytosis, the "reticulocyte haemoglobin "was calculated by multiplying the haemoglobin concentration by the fraction of erythrocytes present as reticulocytes (cf. Giblett, Coleman, Pirzio-Biroli, Donohue, Motulsky, and Finch, 1956). The normal reticulocyte haemoglobin was taken as $0.1-0.3 \mathrm{~g} / 100$

*Supported by grants from the National Health and Medical Research Council. ml. Erythrocyte survival and blood volume studies were carried out using chromium-51 as previously described (Crawford and de Gruchy, 1958); dat 8 were not corrected for the loss of chromium bu elution from erythrocytes. An index of periphera产 haemoglobin destruction was calculated by multi? plying the fraction of erythrocytes apparently destroyed daily $\left[\frac{0.69}{\text { chromium half-life }}\right]$ by the circulating haemoglobin (Veall and Vetter, 1958). The normal value for this index was taken, in terms of haemoglobin, to be $250 \mathrm{mg}$./ kg./day (normal chromium half-life $=28$ days ; circulating haemoglobin $=10$ g. $/ \mathrm{kg}$.). Since the chromium half-life is less than the true half-life, the above formula overestimates peripheral haemoglobin destruction. Nevertheless values in different persons are still comparable.

Serum bilirubin was determined using the method of O'Hagan, Hamilton, Le Breton, and Shaw (1957). In some instances in which serum bilirubin was not measured, the colour of the plasma was recorded. Serum vitamin $\mathbf{B}_{12}$ was measured according to the method of Hutner, Bach, and Ross (1956).

\section{Patients Studied}

The conditions studied were classified as follows:

Congenital Haemolytic Disease (10 Cases).- C Four patients (Cases 1-4) had hereditary spherocytosis, four (Cases 5-8) had non-spherocytic con- 0 genital haemolytic anaemia, one (Case 9) had $\underset{\Phi}{\leftarrow}$ thalassaemia, and one (Case 10) had thalassaemia- $\stackrel{\mathcal{P}}{+}$ sickle cell disease. One patient with hereditary spherocytosis (Case 4) had a megaloblastic marrow, $\bar{O}$ presumably due to folic acid deficiency. His serum $\mathbb{D}$ vitamin $\mathbf{B}_{12}$ was $300 \mu \mu \mathrm{g}$. $/ \mathrm{ml}$. 


\section{Case).}

Paroxysmal Nocturnal Haemoglobinuria (One

Chemical Haemolytic Disease (Seven Cases).Two patients (Cases 12, 13) developed haemolytic anaemia following the administration of phenacetin, and another (Case 14) an acute haemolytic anaemia probably due either to phenylbutazone or dry cleaning solvents. Cases 13 and 14 showed methaemoglobinaemia; in Case 12 spectroscopic examination was not performed. Haemolysis ceased in all patients after the toxic agents were withdrawn and in two (Cases 12, 14) adrenocortical steroids were administered. Four other patients (Cases 15-18) had sulphaemoglobinaemia without evidence of haemolysis.

Disseminated Lupus Erythematosus (Six Cases).In five of these cases the diagnosis was confirmed by the demonstration of L.E. cells; in the other the diagnosis was based on clinical features alone.

Leukaemia, Myelosclerosis, and Malignant Lymphomas (19 Cases). - The diagnosis was established by blood and marrow examinations or by histological examination of biopsy specimens.

\section{Results}

Congenital Haemolytic Disease.-The serum haptoglobins were low in all patients with untreated congenital haemolytic disease (Table I). Not all of the patients in this group were anaemic at the time the serum haptoglobins were determined, although they all showed evidence of increased haemoglobin destruction in the form of increased serum bilirubin and reticulocytehaemoglobin levels.

Paroxysmal Nocturnal Haemoglobinuria.This patient was anaemic and had a low serum haptoglobin level although the serum bilirubin was not increased.

Chemical Haemolytic Anaemia.-The serum haptoglobin levels were reduced in all three patients during the acute haemolytic episode. In Cases 12 and 14 haptoglobin levels returned to normal one month after the acute episode, by which time the haemoglobin value, reticulocyte count, and the serum bilirubin had returned to normal. In patients with sulphaemoglobinaemia without evidence of haemolysis, serum haptoglobins were low-normal in three (Cases 15-17) and high-normal in the fourth.

Disseminated Lupus Erythematosus. - In patients with this disorder the results were variable (Table III). Values were low in three patients (Cases 22-24) who showed evidence of haemolysis in that they were anaemic with a raised reticulocyte count, an increased serum bilirubin, and

TABLE I

SERUM HAPTOGLOBINS IN PATIENTS WITH CONGENITAL HAEMOLYTIC DISEASE

\begin{tabular}{|c|c|c|c|c|c|c|c|}
\hline $\begin{array}{l}\text { Case } \\
\text { No. }\end{array}$ & Diagnosis & Sex & Age & $\begin{array}{l}\text { Haemoglobin } \\
(\mathrm{g} . / 100 \mathrm{ml} .)\end{array}$ & $\begin{array}{l}\text { Reticulocyte- } \\
\text { haemoglobin } \\
(\mathrm{g} . / 100 \mathrm{ml} .)\end{array}$ & $\begin{array}{c}\text { Bilirubin } \\
\text { (mg./100 ml.) }\end{array}$ & $\begin{array}{l}\text { Haptoglobin } \\
\text { (mg./100 ml.) }\end{array}$ \\
\hline $\begin{array}{l}1 \\
2 \\
3 \\
4 \\
5\end{array}$ & $\begin{array}{c}\text { Hereditary spherocytosis } \\
\text { ", ", } \\
\text { Non-spherocytic ", }\end{array}$ & $\begin{array}{l}\mathbf{M} \\
\mathbf{M} \\
\mathbf{F}\end{array}$ & $\begin{array}{l}21 \\
18 \\
29 \\
64\end{array}$ & $\begin{array}{r}14 \cdot 6 \\
16 \cdot 9 \\
10 \cdot 9 \\
6 \cdot 5\end{array}$ & $\begin{array}{l}0 \cdot 6 \\
2 \cdot 7 \\
1 \cdot 7 \\
0 \cdot 4\end{array}$ & $\begin{array}{l}1.9 \\
2.4 \\
1.6 \\
1.5\end{array}$ & $\begin{array}{r}<10 \\
<10 \\
19 \\
<10\end{array}$ \\
\hline $\begin{array}{r}6 \\
7 \\
8 \\
9 \\
10\end{array}$ & $\begin{array}{c}\text { haemolytic anaemia } \\
\text { ", ", } \\
\text { Thalassaemia }, ", \\
\text {," -sickle celi disease }\end{array}$ & $\begin{array}{l}\mathbf{F} \\
\mathbf{M} \\
\mathbf{M} \\
\mathbf{M} \\
\mathbf{M} \\
\mathbf{M}\end{array}$ & $\begin{array}{r}9 \\
43 \\
45 \\
9 \\
23 \\
2\end{array}$ & $\begin{array}{r}3 \cdot 7 \\
6 \cdot 2 \\
12 \cdot 0 \\
7 \cdot 4 \\
7 \cdot 9 \\
7 \cdot 7\end{array}$ & $\begin{array}{l}0.4 \\
1.6 \\
2 \cdot 2 \\
0.3 \\
-\end{array}$ & $\begin{array}{c}1 \cdot 7 \\
\text { Plasma jaundiced } \\
2 \cdot 5 \\
2 \cdot 0 \\
2 \cdot 0 \\
-\end{array}$ & $\begin{array}{r}11 \\
11 \\
<10 \\
15 \\
<10 \\
12\end{array}$ \\
\hline
\end{tabular}

TABLE II

SERUM HAPTOGLOBINS IN PATIENTS WITH PAROXYSMAL NOCTURNAL HAEMOGLOBINURIA (CASE 11), CHEMICAL HAEMOLYTIC ANAEMIA (CASES 12-14), AND SULPHAEMOGLOBINAEMIA (CASES 15-18)

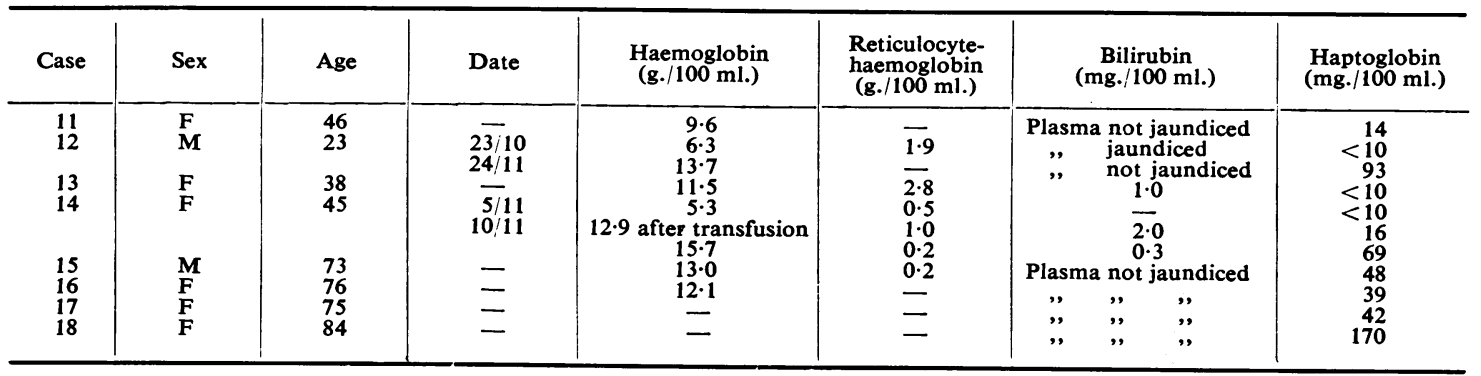


TABLE III

SERUM HAPTOGLOBINS IN PATIENTS WITH DISSEMINATED LUPUS ERYTHEMATOSUS

\begin{tabular}{|c|c|c|c|c|c|c|c|}
\hline $\begin{array}{l}\text { Case } \\
\text { No. }\end{array}$ & Sex & Age & Date & $\underset{(\mathrm{g} . / 100 \mathrm{ml} .)}{\text { Haemoglobin }}$ & $\begin{array}{c}\text { Reticulocyte- } \\
\text { haemoglobin } \\
(\mathrm{g} . / 100 \mathrm{ml} .)\end{array}$ & $\begin{array}{c}\text { Bilirubin } \\
(\mathrm{mg} . / 100 \mathrm{ml} .)\end{array}$ & $\begin{array}{l}\text { Haptoglobin } \\
(\mathrm{mg} \cdot / 100 \mathrm{ml} .)\end{array}$ \\
\hline $\begin{array}{l}19 \\
20 \\
21 \\
22 \\
23 \\
24\end{array}$ & $\begin{array}{l}\mathbf{F} \\
\mathbf{F} \\
\mathbf{M} \\
\mathbf{F} \\
\mathbf{M} \\
\mathbf{F}\end{array}$ & $\begin{array}{l}60 \\
17 \\
55 \\
20 \\
38 \\
47\end{array}$ & $\begin{array}{c}= \\
= \\
= \\
\overline{7 / 7 / 59} \\
16 / 7 / 59^{*} \\
27 / 10 / 59^{*} \\
19 / 1 / 60^{*} \\
21 / 2 / 60^{*}\end{array}$ & \begin{tabular}{r|}
$11 \cdot 1$ \\
$12 \cdot 1$ \\
$12 \cdot 0$ \\
$11 \cdot 3$ \\
$8 \cdot 4$ \\
$7 \cdot 2$ \\
$10 \cdot 3$ \\
$14 \cdot 2$ \\
$13 \cdot 2$ \\
$14 \cdot 1$
\end{tabular} & $\begin{array}{l}0.1 \\
0.2 \\
0.2 \\
- \\
\overline{0.1} \\
0.7 \\
0.7 \\
\overline{0.6}\end{array}$ & $\begin{array}{c}0.5 \\
0.3 \\
\text { Plasma not jaundiced } \\
2.5 \\
\text { Plasma jaundiced } \\
3.7 \\
0.8 \\
\overline{1.2} \\
1.2\end{array}$ & $\begin{array}{r}250 \\
144 \\
250 \\
<10 \\
<10 \\
<10 \\
<10 \\
32 \\
68 \\
115\end{array}$ \\
\hline
\end{tabular}

* On adrenocortical steroid therapy.

TABLE IV

SERUM HAPTOGLOBINS IN PATIENTS WITH MYELOSCLEROSIS, LEUKAEMIA, OR MALIGNANT LYMPHOMAS

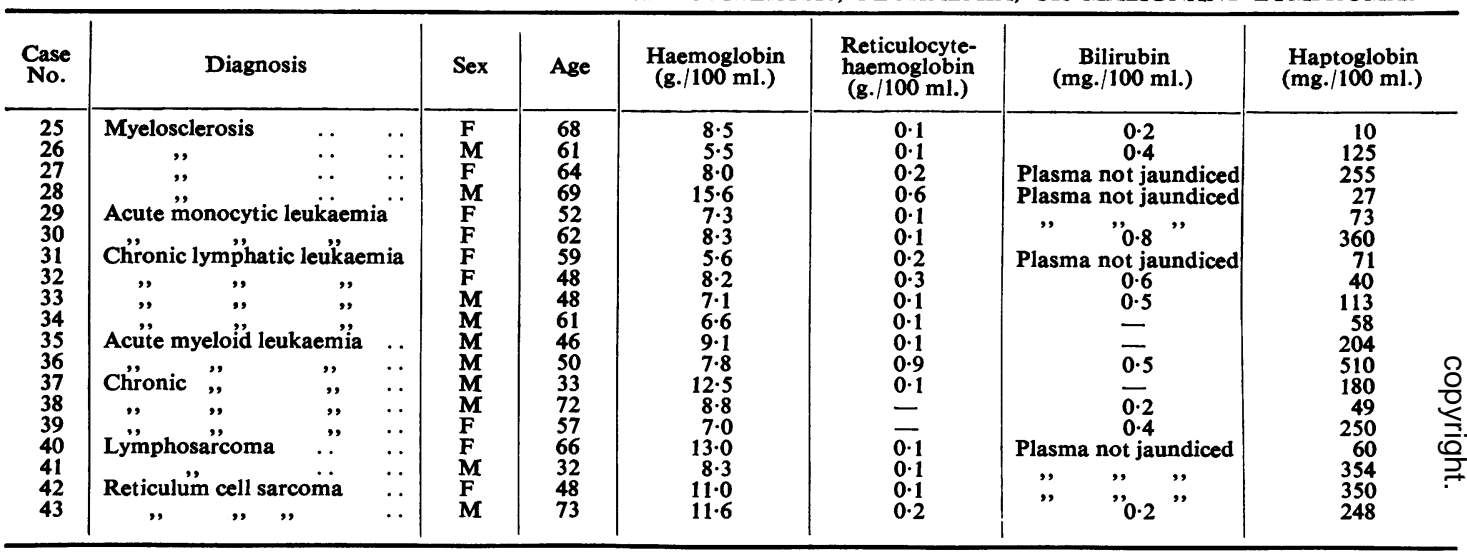

an excess urobilinogen in the urine. In one of these patients (Case 24), who was given prednisolone, the serum haptoglobin slowly increased over seven months to reach the mean normal level in spite of continuing haemolysis as evidenced by raised reticulocyte haemoglobin and bilirubin levels. In the other three patients with no evidence of haemolysis the serum haptoglobins were either normal or high.

Myelosclerosis, Leukaemia, and Malignant Lymphomas.-With one exception the serum haptoglobins in patients with these disorders were either normal or increased (Table IV). The exception was a patient with myelosclerosis who was anaemic; she showed no clinical evidence of haemolysis, but her chromium $T / \frac{1}{2}$ was moderately reduced. Most of the other patients were anaemic, but none had elevated serum bilirubin levels and in only two was the reticulocyte haemoglobin raised. In these patients the haptoglobin levels were low-normal and high, respectively.

Haemoglobin Destruction Rates.-These were calculated in some patients (Table V). With few exceptions haptoglobin values tended to be low in those patients with high haemoglobin destruction rates and high serum bilirubin levels.

One patient (Case 4) had a peripheral haemoglobin destruction rate only slightly elevated although the serum bilirubin was $1.5 \mathrm{mg} . / 100 \mathrm{ml}$.

TABLE V

SERUM HAPTOGLOBIN AND PERIPHERAL HAEMOGLOBIN DESTRUCTION

\begin{tabular}{|c|c|c|c|c|c|}
\hline $\begin{array}{l}\text { Case* } \\
\text { No. }\end{array}$ & $\begin{array}{c}\text { Haemo- } \\
\text { globin } \\
(\mathrm{g} \cdot / \\
100 \mathrm{ml} .)\end{array}$ & $\begin{array}{c}\text { Chromium } \\
\text { Half-life } \\
\text { (days) }\end{array}$ & $\begin{array}{c}\text { Peripheral } \\
\text { "Haemo- } \\
\text { globin } \\
\text { Destruc- } \\
\text { tion" } \\
\text { (mg./kg./ } \\
\text { day) }\end{array}$ & $\begin{array}{c}\text { Bilirubin } \\
\text { (mg./ } \\
100 \mathrm{ml} .)\end{array}$ & $\begin{array}{l}\text { Hapto- } \\
\text { globin } \\
\text { (mg./ } \\
100 \mathrm{ml} .)\end{array}$ \\
\hline $\begin{array}{r}2 \\
3 \\
1 \\
4 \\
27\end{array}$ & $\begin{array}{r}16.9 \\
10.9 \\
14.6 \\
6.5 \\
8.0\end{array}$ & $\begin{array}{r}6 \\
8 \\
13 \\
9 \\
16\end{array}$ & $\begin{array}{r}1,430 \\
730 \\
590 \\
370 \\
310\end{array}$ & $\begin{array}{c}2.4 \\
1.6 \\
1.9 \\
1.5 \\
\text { Plasma not }\end{array}$ & $\begin{array}{r}<10 \\
19 \\
<10 \\
<10 \\
90\end{array}$ \\
\hline $\begin{array}{l}32 \\
31 \\
25 \\
42\end{array}$ & $\begin{array}{r}8 \cdot 2 \\
5 \cdot 6 \\
8 \cdot 5 \\
11 \cdot 0\end{array}$ & $\begin{array}{l}17 \\
14 \\
18 \\
20\end{array}$ & $\begin{array}{l}310 \\
300 \\
280 \\
210\end{array}$ & $\begin{array}{c}0.6 \\
0.2 \\
\text { Plasma not }\end{array}$ & $\begin{array}{r}60 \\
40 \\
<10 \\
350\end{array}$ \\
\hline $\begin{array}{l}27 \\
34 \\
33\end{array}$ & $\begin{array}{l}8 \cdot 3 \\
7 \cdot 9 \\
4 \cdot 2\end{array}$ & $\begin{array}{l}23 \\
25 \\
17\end{array}$ & $\begin{array}{l}180 \\
180 \\
170\end{array}$ & $\begin{array}{c}\text { Jaunarced } \\
\text { ", } \\
0.5\end{array}$ & $\begin{array}{r}120 \\
58 \\
113\end{array}$ \\
\hline
\end{tabular}

- Cases have been arranged in order of decreasing peripheral haemoglobin destruction. 
However, this patient had a megaloblastic marrow, so that it is possible that haemolysis of immature cells was causing a raised bilirubin and a low haptoglobin level without the peripheral haemoglobin destruction rate being greatly affected (Owen, Carew, Cowling, Hoban, and Smith, 1960b).

Effect of Splenectomy.-In four cases serum haptoglobins were measured before and after splenectomy (Table VI). In three cases (all hereditary spherocytosis) the serum haptoglobins were low before the operation while the reticulocyte-haemoglobin and the serum bilirubin levels were increased. After operation, all three parameters returned to normal values. In the other patient with myelosclerosis all three parameters were within normal limits before and after the operation.

TABLE VI

EFFECT OF SPLENECTOMY ON SERUM HAPTOGLOBINS

\begin{tabular}{|c|c|c|c|c|c|}
\hline $\begin{array}{l}\text { Case } \\
\text { No. }\end{array}$ & $\begin{array}{c}\text { Time } \\
\text { Relative } \\
\text { to } \\
\text { Splenec- } \\
\text { tomy }\end{array}$ & $\begin{array}{c}\text { Haemo- } \\
\text { globin } \\
\text { (g./ } \\
100 \mathrm{ml} .)\end{array}$ & $\begin{array}{c}\text { Reticulo- } \\
\text { cyte- } \\
\text { haemo- } \\
\text { globin } \\
\text { (g. } / 100 \mathrm{ml} .)\end{array}$ & $\begin{array}{c}\text { Bilirubin } \\
\text { (mg./ } \\
100 \mathrm{ml} .)\end{array}$ & $\begin{array}{c}\text { Hapto- } \\
\text { globin } \\
\text { (mg./ } \\
100 \mathrm{ml} .)\end{array}$ \\
\hline 1 & $\begin{array}{l}\text { Before } \\
\text { After }\end{array}$ & $\begin{array}{l}14.6 \\
15.9\end{array}$ & $\begin{array}{l}0 \cdot 6 \\
0.2\end{array}$ & $\begin{array}{c}1.9 \\
\text { Plasma not } \\
\text { jaundiced }\end{array}$ & $\begin{array}{l}<10 \\
60\end{array}$ \\
\hline \multirow[t]{2}{*}{3} & $\begin{array}{l}\text { Before } \\
\text { "’2 days } \\
+5 \text {," }\end{array}$ & $\begin{array}{l}10 \cdot 9 \\
12 \cdot 6 \\
12 \cdot 8 \\
12 \cdot 7\end{array}$ & $\begin{array}{l}1 \cdot 7 \\
2 \cdot 4 \\
1 \cdot 0 \\
0 \cdot 3\end{array}$ & $\begin{array}{c}1.6 \\
1.7 \\
\text { Plasma not }\end{array}$ & $\begin{array}{l}19 \\
12 \\
11 \\
22\end{array}$ \\
\hline & $\begin{array}{l}+13 \text { ", } \\
+22 ",\end{array}$ & $\begin{array}{l}12.8 \\
13.9\end{array}$ & $\begin{array}{l}0.1 \\
0.2\end{array}$ & $\frac{0.2}{-}$ & $\begin{array}{l}120 \\
147\end{array}$ \\
\hline 4 & $\begin{array}{l}\text { Before } \\
\text { After }\end{array}$ & $\begin{array}{l}6 \cdot 5 \\
9 \cdot 3\end{array}$ & $\begin{array}{l}0.4 \\
0.1\end{array}$ & $\begin{array}{c}1.5 \\
\text { Plasma not } \\
\text { jaundiced }\end{array}$ & $\begin{array}{l}<10 \\
155\end{array}$ \\
\hline 27 & $\begin{array}{l}\text { Before } \\
\text { After }\end{array}$ & $\begin{array}{l}8 \cdot 0 \\
8 \cdot 3\end{array}$ & $\begin{array}{l}0.2 \\
0.2\end{array}$ & ", & $\begin{array}{r}90 \\
120\end{array}$ \\
\hline
\end{tabular}

\section{Discussion}

The results reported here indicate that the serum haptoglobins are usually low in patients with increased haemolysis. This confirms the earlier reports cited above and others which have appeared since this investigation began (Nyman, Gydell, and Nosslin, 1959 ; Lathem and Jensen, 1959 ; Brus and Lewis, 1959).

In a previous paper (Owen, Carew, Cowling, Hoban, and Smith, 1960b), the view was put forward that a low serum haptoglobin level associated with increased haemolysis is most likely due to the formation of a haemoglobinhaptoglobin complex in the plasma and to its subsequent removal from the circulation. The finding (Table V) of a negative correlation between haemoglobin destruction and serum haptoglobin supports this view, as does the negative correlation between serum bilirubin and haptoglobin levels observed in this investigation and in a previous study (Owen et al., 1960b). Correlations between serum haptoglobin levels and faecal urobilinogen and endogenous blood carbon monoxide respectively (Nyman et al., 1959) add additional support. The fact that the serum haptoglobins returned to normal in hereditary spherocytosis following splenectomy which resulted in complete clinical and haematological remission is further evidence that low serum haptoglobins in haemolytic states are related directly to the haemolytic process. Similar observations following splenectomy have been made by Chevallier and Wolpé (1945) and Brus and Lewis (1959).

Brus and Lewis (1959) demonstrated a correlation between haemoglobin destruction and serum haptoglobin levels; they found that in most of their cases the haptoglobins were absent when the haemoglobin turnover per day exceeded twice the normal, rate. The data in Table $\mathrm{V}$ support this conclusion that the reduction in serum haptoglobins is related to the amount of haemoglobin destroyed. Thus Cases 1-4, patients with congenital haemolytic anaemia, in whom there was a significant increase in peripheral haemoglobin destruction, had low haptoglobin values. In the other cases listed (with the exception of Case 25) the calculated peripheral haemoglobin destruction rates were normal or only slightly increased and there was no decrease in serum haptoglobins; nevertheless most of these patients had a haemolytic state as evidenced by shortened red cell survival times. In these patients, all of whom had myelosclerosis, leukaemia, or lymphoma, the bone marrow was presumably unable to increase significantly the rate of erythropoiesis to compensate for the shortened red cell life span, as it could in the cases of congenital haemolytic disease. There are two possible explanations for the absence of a fall in serum haptoglobins in these cases: (1) The fact that the peripheral haemoglobin destruction rate was not significantly increased; (2) the underlying disorder may have caused some increase in haptoglobins (see below).

It appears that haptoglobins are reduced in both intravascular haemolysis, in which the haemoglobin is released into the circulation directly from disintegrating cells, and extravascular haemolysis in which red cells break down in the cells of the reticulo-endothelial system. Thus values were reduced in paroxysmal nocturnal haemoglobinuria (Case 11) in which haemolysis is 
known to occur intravascularly, and in the cases of chemical haemolytic anaemia (Cases 12-14) in which the haemolysis was almost certainly occurring intravascularly. Low values were found in all cases of hereditary spherocytosis in which haemolysis has to date been regarded as occurring extravascularly. In the case of extravascular haemolysis some of the haemoglobin is presumably released from the reticulo-endothelial cells into the circulating plasma to form the haemoglobin-haptoglobin complex. Brus and Lewis (1959) in their extensive study also found that haptoglobin levels were reduced in both intravascular and extravascular haemolysis.

In some of the patients with leukaemia, myelosclerosis, and lymphomas the serum haptoglobins were increased. Raised serum haptoglobin levels occur commonly in other types of neoplasia and in disorders associated with tissue destruction or inflammation such as infections, collagen disease, trauma, and post-operative states (Chevallier and Wolpé, 1945 ; Jayle and Boussier, 1955 ; Allison and Blumberg, 1958; Nyman, 1959; Owen, Mackay, and Got, 1959 ; Brus and Lewis, 1959). The reason for this is not clear. It is probable that it is due to increased production of serum haptoglobins. Whatever the reason this is obviously a complicating factor in assessing the significance of serum haptoglobin levels in a particular case. Thus, an increased loss of haptoglobin (as a complex with haemoglobin) may be balanced by an increased production. Presumed examples have already been noted. A patient suffering from severe untreated pernicious anaemia and a fractured femur was found to have a normal haptoglobin level (Owen et al., 1960b) though haptoglobin levels are usually considerably reduced in pernicious anaemia. Another patient with congenital haemolytic anaemia had normal haptoglobins during an upper respiratory tract infection though the serum haptoglobins were usually low (Chevallier and Wolpé, 1945). We have observed normal or raised serum haptoglobins in several patients with severe burns even though the patients had haemoglobinuria presumably due to haemolysis. Serum haptoglobins may also be increased by the administration of adrenocortical steroid hormones (Brus and Lewis, 1959). Case 24 showed a progressive rise in haptoglobins while under treatment with steroids; while this may have been in part due to a lessening in the rate of haemolysis, it probably was not entirely so; as signs of active haemolysis persisted during treatment.
From the point of view of the clinician the most important question is the value of serum haptoglobin determination in the diagnosis of haemolysis. Nosslin and Nyman (1958), in their preliminary communication, stated that "determination of the haptoglobin level is useful in the investigation of anaemia. A normal or raised level argues strongly against haemolysis; whereas low level in the absence of hepatic disease indicates haemolysis." It would certainly appear from other reports and from our observations that a low level, in the absence of hepatic disease, does indicate haemolysis. However, both our results and those of Brus and Lewis (1959) definitely indicate that a normal or raised level does not exclude haemolysis. Haemolysis without decrease in serum haptoglobins may occur (1) in the presence of malignancy or infection or adrenocortical steroid administration, and (2) when haemolysis is associated with impairment of bone marrow function with the result that the daily rate of haemoglobin destruction is not significantly increased; this is seen particularly in the leukaemias and malignant lymphomas.

We should like to thank members of the honorary medical staff, St. Vincent's Hospital, and Dr. S.O Williams and Dr. J. Maclean for their kindness in allowing us to study patients under their care. We are grateful also to Dr. J. P. Carew for haematological studies, to Dr. D. Cowling for the serum vitamin $B_{12}$ assay, to Dr. R. Williams and Dr. G. Hale for performing the chromium survival studies, and to Miss A. Jowett and Mr. R. Podanyi for technical assistance.

\section{REFERENCES}

Allison, A. C. (1958). Proc. roy. Soc. Med., 51, 641.

and Blumberg, B. S. (1958). Arthr. and Rheum., 1, 239.

Brus, I., and Lewis, S. M. (1959). Brit. J. Haemat., 5, 348.

Chevallier, P., and Wolpe, R. (1945). Sang, 16, 327, 486.

Crawford, H., and de Gruchy, G. C. (1958). Med. J. Aust., 1, 657.

Dacie, J. V. (1956). Practical Haematology, 2nd ed. Churchill, London.

Giblett, E. R., Coleman, D. H., Pirzio-Biroli, G., Donohue, D. M., Motulsky, A. G., and Finch, C. A. (1956). Blood, 11, 291.

Hutner, S. H., Bach, M. K., and Ross, G. I. M. (1956). J. Protozool., 3, ioi.

Jayle, M. F., and Boussier, G. (1955). Expos. ann. Biochim. méd., $17,157$.

Lathem, W., and Jensen, W. N. (1959). Blood, 14, 1047.

Neale, F. C., Aber, G. M., and Northam, B. E. (1958). J. clin. Path. $11,206$.

Nosslin, B. F., and Nyman, M. (1958). Lancet, 1, 1000.

Nyman, M. (1959). Scand. J. clin. Lab. Invest., Suppl. 39.

Gydell, K., and Nosslin, B. (1959). Clin. Chim. Acta, 4, 82.

O'Hagan, J. E., Hamilton, T., Le Breton, E. G., and Shaw, A. E. (1957). Clin. Chem., 3, 609.

Owen, J. A., Better, F. C., and Hoban, J. (1960a). J. clin. Path., 13, 163 .

Carew, J. P., Cowling, C. D., Hoban, J., and Smith, H. (1960b) Brit. J. Haemat., 6, 242.

_ Mackay, I. R., and Got, C. (1959). Brit. med. J., 1, 1454.

Veall, N., and Vetter, H. (1958). Radioisotope Techniques in Clinical Research and Diagnosis. Butterworth, London. 